\title{
PENTINGNYA MENJAGA KESEHATAN DI MASA PANDEMI COVID-19 PADA REMAJA DI PANTI AISYIYAH LUBUK MINTURUN
}

\section{THE IMPORTANCE OF MAINTAINING HEALTH IN THE PANDEMIC TIME OF COVID-19 IN ADOLESCENTS AT PANTI AISYIYAH LUBUK MINTURUN}

\author{
Rini Rahmayanti", Fitri Wahyuni, Velga Yazia, Delvi Handayani, \\ Hidayatul Hasni
}

\author{
STIKes MERCUBAKTIJAYA Padang \\ Jalan Jamal Jamil Pondok Kopi Siteba Padang \\ *Email: rinie.rahmayanti@gmail.com
}

\begin{abstract}
ABSTRAK
Seiring dengan peningkatan kasus masalah reproduksi pada remaja sekarang ini, ditambah dengan kondisi pandemi Covid-19 yang dapat menyebabkan kelengahan remaja dalam kebersihan reproduksi berpotensi menimbulkan masalah kesehatan reproduksi pada remaja putri di panti asuhan. Tujuan kegiatan pengabdian ini adalah untuk meningkatkan pengetahuan dan berfikir kritis remaja putri tentang perubahan fisik remaja di rumah serta untuk meningkatkan pengetahuan remaja putri tentang manajemen kebersihan menstruasi selama masa pandemi Covid-19. Kegiatan dilaksanakan secara online menggunakan aplikasi Zoom pada tanggal 4 Juni 2020 dengan menggunakan metode ceramah. Metode ceramah dipilih untuk memberikan penjelasan tentang manajemen kebersihan menstruasi selama pandemi Covid-19 dan pengenalan perubahan fisik remaja selama di rumah. Metode tanya jawab juga dilaksanakan agar peserta dapat menggali pengetahuan sebanyakbanyaknya tentang materi yang disampaikan. Hasil kegiatan menunjukkan adanya peningkatan pengetahuan, pemahaman, dan kemampuan peserta dalam memahami materi yang disampaikan. Hasil post-test menunjukkan adanya peningkatan persentase sampai $100 \%$ untuk pertanyaan terkait pengetahuan tentang menstruasi yang dikatakan normal apabila terjadi selama di rumah, perubahan fisik yang terjadi pada seseorang jika beranjak remaja, dan cara kebersihan menstruasi selama Covid-19.
\end{abstract}

Kata Kunci: remaja, kesehatan, Pandemi Covid-19, Panti Asuhan

\section{ABSTRACT}

Along with the increase in cases of reproductive problems in adolescents today, and the occurrence of the Covid-19 pandemic case which can cause adolescents to be negligent in reproductive hygiene has the potential to cause reproductive health problems in young women in orphanages. The purpose of this service activity is to increase the knowledge and critical thinking of young women about the physical changes of adolescents at home and to increase the knowledge of young women about menstrual hygiene management during the Covid-19 pandemic. The activity was carried out online using the Zoom application on June 4, 2020 using the method lecture. The lecture method was chosen to provide an explanation of menstrual hygiene management during the Covid-19 pandemic and an introduction to the physical changes of adolescents while at home. The question and answer method is also implemented so that participants can gain as much knowledge as possible about the material presented. The results of the activity indicated an increase in the knowledge, understanding, and ability of the participants in understanding the material presented. The post-test results show an increase in the percentage of up to $100 \%$ for questions related to knowledge of menstruation which is said to be normal when it occurs at home, physical changes that occur in a person when they are teenagers, and how to clean menstruation during Covid-19.

Keywords: adolescents, health, Covid-19 Pandemic, Orphanage

\section{PENDAHULUAN}

Panti Asuhan Aisyiyah Lubuk Minturun merupakan salah satu panti asuhan di Kota Padang yang beralamat di jalan Raya Lubuk Minturun Air Dingin, Kelurahan Balai Gadang, Kecamatan Koto Tangah, Kota Padang. Panti ini telah banyak menyantuni anak- 
anak yatim, piatu, dan dhuafa yang berasal dari Sumatera Barat dan luar Sumatera Barat. Panti asuhan ini memiliki jumlah anak asuh yang berstatus siswa sebanyak 20 orang yang terdiri atas kalangan SD sampai SMA.

Survei pendahuluan yang dilakukan terhadap ketua yayasan dan ibu asuh di Panti Asuhan Aisyiyah Lubuk Minturun menunjukkan bahwa selama pandemi covid-19, kegiatan yang biasa dilakukan terfokus pada proses belajar dan beberapa kegiatan yang menjadi agenda wajib atau rutinitas di panti. Ibu asuh juga mengatakan bahwa belum pernah ada pendidikan kesehatan reproduksi remala selama masa pandemi covid-19 kepada anak-anak panti. Kegiatan di panti lebih difokuskan kepada rutinitas sehari-hari.

Selama pandemi covid-19, kondisi panti asuhan cocok untuk menjadi sasaran kegiatan pengabdian jika ditinjau dari fasilitas dan kenyamanan yang berbeda dengan kehidupan di rumah. Penghuni panti asuhan memang memiliki pengasuh, namun tidak sepenuhnya bisa nyaman seperti di rumah sendiri. Mereka harus terbiasa mandiri dengan keadaan. Keadaan inilah yang mengakibatkan rentan terhadap permasalahan reproduksi. Kondisi pandemi covid-19 dapat memperburuk keadaan jika tidak ada arahan terkait kesehatan reproduksi seperti pemahaman perubahan fisik remaja dan manajemen kebersihan mentruasi selama pandemi covid-19.

Berdasarkan hal ini, perlu dilakukan sebuah pendidikan kesehatan tentang kesehatan reproduksi dengan metode daring terhadap anak-anak panti, terutama remaja putri yang baru menginjak masa remaja. Secara psikologis remaja mulai mengalami masa peralihan yang membutuhkan arahan termasuk berkaitan dengan kesehatan reproduksinya. Perubahan yang terjadi pada remaja, baik secara fisik, sosial, maupun psikologis, menuntut remaja untuk memahami pertumbuhan dan perkembangan yang mereka alami agar mereka mampu melewati masa remajanya dengan baik. Metode daring melalui aplikasi zoom merupakan salah satu pilihan untuk pemberian pendidikan kesehatan dengan tetap mengutamakan protokol kesehatan selama pandemi Covid-19.

Kurangnya pengetahuan remaja terkait kebersihan alat reproduksi selama menstruasi dapat menyebabkan infeksi saluran reproduksi. Remaja putri rentan sekali terhadap infeksi organ reproduksi yang disebabkan kurangnya perilaku dalam merawat kebersihan diri terutama saat mengalami menstruasi (Kusmiran, 2012). Remaja putri memiliki tingkat perhatian yang rendah terhadap kesehatan reproduksi. Berdasarkan data WHO tahun 2010, angka kejadian infeksi saluran reproduksi (ISR) tertinggi di dunia adalah pada usia remaja (35\%-42\%) dan dewasa muda (27\%-40\%). Angka prevelensi candidiasis (25\%-50\%), bacterialvaginosis $(20 \%-40 \%)$ dan trichomoniasis (5\%-15\%). Negara Indonesia memiliki 
iklim yang panas dan lembab sehingga wanita Indonesia lebih rentan mengalami ISR, berdasarkan data statistik di Indonesia tahun 2012 dari 43,3 juta jiwa remaja putri berusia 10-14 tahun berperilaku hygiene yang buruk (Priyitno, 2014).

Remaja putri rentan sekali terhadap infeksi organ reproduksi, hal itu terjadi dikarenakan kurangnya perilaku dalam merawat kebersihan diri terutama saat mengalami menstruasi (Kusmiran, 2012). Remaja putri memiliki tingkat perhatian yang rendah terhadap kesehatan reproduksi. Berdasarkan data WHO tahun 2010, angka kejadian infeksi saluran reproduksi (ISR) tertinggi di dunia adalah pada usia remaja (35\%-42\%) dan dewasa muda (27\%-40\%). Angka prevelensi candidiasis (25\%-50\%), bacterialvaginosis (20\%-40\%) dan trichomoniasis (5\%-15\%). Negara indonesia memiliki iklim yang panas dan lembab sehingga wanita indonesia lebih rentan mengalami ISR, berdasarkan data statistik di indonesia tahun 2012 dari 43,3 juta jiwa remaja putri berusia 10-14 tahun berperilaku hygiene yang buruk (Priyitno, 2014)

Remaja perempuan yang mempunyai pengetahuan yang lebih baik tentang personal hygiene saat menstruasi berisiko lebih rendah terkena infeksi saluran reproduksi bila dibanding wanita yang mempunyai pengetahuan yang kurang, Oleh karena itu, peningkatan pengetahuan personal hygiene saat menstruasi sejak dini dapat mengurangi angka kejadian ISR (Dasgupta, 2008). Pengetahuan dapat dipengaruhi oleh beberapa faktor, misalnya sumber informasi utama, usia, pengalaman dan lingkungan (Cahyono, 2016).

\section{BAHAN DAN METODE}

Berdasarkan analisa situasi dan juga permasalahan yang ada, maka kegiatan pemberian penyuluhan kesehatan tentang pentingnya menjaga kesehatan pada remaja di masa pandemi Covid-19 adalah solusi yang ditawarkan pada kegiatan pengabdian masyarakat ini. Pendidikan kesehatan diberikan melalui daring dengan aplikasi zoom. Setelah mengikuti kegiatan pengabdian masyarakat diharapkan peserta memahami pentingnya menjaga kesehatan pada remaja di masa pandemi covid-19. Adapun tujuan khusus dari penyuluhan ini adalah: (1) Penyuluhan tentang perubahan fisik remaja selama di rumah, dan (2) Penyuluhan tentang manajemen kebersihan menstruasi selama pandemi covid-19.

Kegiatan pengabdian masyarakat ini dilakukan dengan menggunakan dua metode sebagai berikut:

1. Ceramah melalui zoom 
a. Dilakukan untuk menjelaskan teori tentang perubahan fisik pada remaja selama di rumah.

b. Dilakukan untuk menjelaskan manajemen menstruasi pada remaja selama pandemi covid-19.

2. Diskusi

a. Dilakukan dengan memberikan kesempatan kepada remaja untuk mengeluarkan pendapat/pertanyaan tentang materi yang masih kurang dipahami.

b. Dilakukan untuk memberikan kesempatan kepada remaja untuk berpendapat atau bertanya sesuai materi.

Pelaksanaan kegiatan pengabdian pada masyarakat ini dilaksanakan secara daring menggunakan aplikasi zoom mengingat situasi pandemi Covid-19. Kegiatan ini dilaksanakan pada hari Kamis tanggal 4 Juni 2020 jam 14.00-15.30 WIB.

\section{HASIL DAN PEMBAHASAN}

Kegiatan pengabdian pada masyarakat dilaksanakan dengan menggunakan metode ceramah. Materi yang disampaikan dengan menggunakan metode ceramah yaitu "manajemen kebersihan menstruasi selama pandemi Covid-19 dan kenali perubahan fisik remaja selama di rumah". Setelah penyampaikan materi melalui metode ceramah selesai dilakukan, maka berikutnya digunakan metode tanya jawab yang memungkinkan peserta dapat menggali pengetahuan yang sebanyak-banyaknya tentang materi yang disampaikan oleh pemateri.

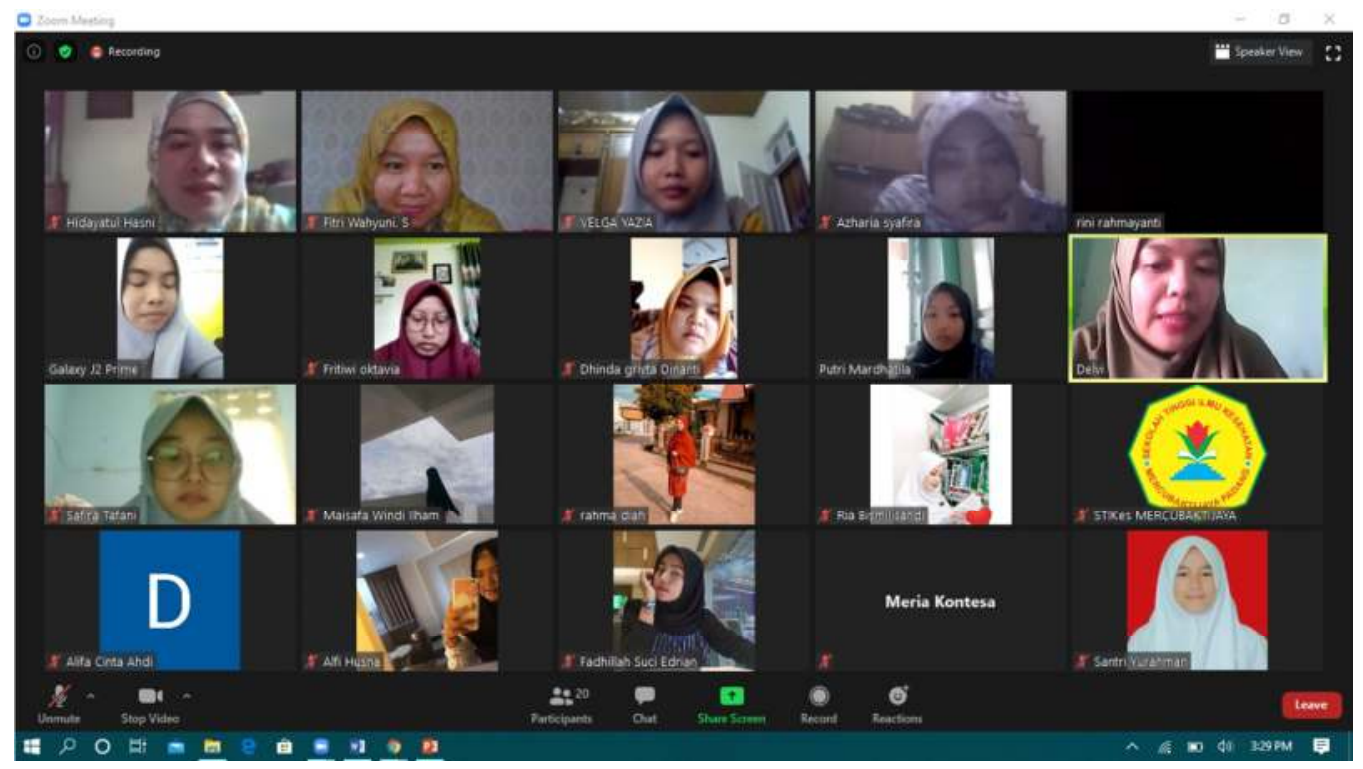

Gambar 1. Pelaksanaan Kegiatan Secara Daring 
Kegiatan pengabdian pada masyarakat ini dimulai pada jam 14.15, terlamat 15 menit dari jadwal yang sudah ditentukan karena menunggu kelengkapan peserta. Jumlah audiens yang mengikuti kegiatan ini sebanyak 20 orang. Seluruh tim terlibat penuh dan berperan aktif dalam kegiatan pengabdian kepada masyarakat. Para peserta terlihat sangat antusias terhadap materi yang disampaikan. Sebelum materi disampaikan, peserta diberikan Pretest terlebih dahulu, dan di akhir sesi penyampaian materi diberikan post-test yang bertujuan untuk mengevaluasi pemahaman peserta terhadap materi yang disampaikan. Hasil evaluasi pre-test dan pos-test dapat dilihat pada Tabel 1.

\section{Tabel 1. Hasil Kuesioner}

\begin{tabular}{|c|c|c|c|c|c|}
\hline \multirow{3}{*}{ No } & \multirow{3}{*}{ Daftar Pertanyaan } & \multicolumn{4}{|c|}{ Presentase Jawaban Peserta } \\
\hline & & \multicolumn{2}{|c|}{ Pre-Test } & \multicolumn{2}{|c|}{ Post-Test } \\
\hline & & Benar & Salah & Benar & Salah \\
\hline 1 & $\begin{array}{l}\text { Salah satu cara MKM selama Covid adalah } \\
\text { tetap sehat dan bugar, hal yang perlu dilakukan } \\
\text { oleh remaja putri adalah, kecuali? }\end{array}$ & $70 \%$ & $30 \%$ & $80 \%$ & $20 \%$ \\
\hline 2 & $\begin{array}{l}\text { Kompenen tubuh yang meluruh pada saat } \\
\text { menstruasi adalah... }\end{array}$ & $40 \%$ & $60 \%$ & $60 \%$ & $40 \%$ \\
\hline 3 & $\begin{array}{l}\text { Tantangan yang dialami remaja dalam } \\
\text { melakukan MKM selama covid-19 adalah..., } \\
\text { kecuali... }\end{array}$ & $50 \%$ & $50 \%$ & $90 \%$ & $10 \%$ \\
\hline 4 & $\begin{array}{l}\text { MKM merupakan istilah yang sering disebut } \\
\text { dalam pengelolaan menstruasi. Kepanjangan } \\
\text { MKM adalah... }\end{array}$ & $20 \%$ & $80 \%$ & $80 \%$ & $20 \%$ \\
\hline 5 & $\begin{array}{l}\text { Hal yang sangat ditakutkan jika remaja telah } \\
\text { memasuki masa reproduksi adalah... }\end{array}$ & $50 \%$ & $50 \%$ & $90 \%$ & $10 \%$ \\
\hline 6 & $\begin{array}{l}\text { Mentruasi dikatakan normal apabila terjadi } \\
\text { selama? }\end{array}$ & $40 \%$ & $60 \%$ & $100 \%$ & $0 \%$ \\
\hline 7 & $\begin{array}{l}\text { Perubahan fisik yang terjadi pada seseorang } \\
\text { yang beranjak remaja adalah..., kecuali... }\end{array}$ & $30 \%$ & $70 \%$ & $100 \%$ & $0 \%$ \\
\hline 8 & $\begin{array}{l}\text { Protokol kesehatan yang perlu dipatuhi oleh } \\
\text { remaja putri selama masa pandemi } \\
\text { berhubungan MKM adalah..., } \text {, kecuali... }\end{array}$ & $40 \%$ & $60 \%$ & $70 \%$ & $30 \%$ \\
\hline 9 & $\begin{array}{l}\text { Kelompok usia remaja menengah adalah berada } \\
\text { pada rentang usia? }\end{array}$ & $40 \%$ & $60 \%$ & $90 \%$ & $10 \%$ \\
\hline 10 & $\begin{array}{l}\text { Salah satu cara menjaga kebersihan menstruasi } \\
\text { selama covid-19 adalah..., kecuali... }\end{array}$ & $80 \%$ & $20 \%$ & $100 \%$ & $0 \%$ \\
\hline
\end{tabular}

Berdasarkan hasil kuesioner pada Tabel 1 terlihat adanya peningkatan pengetahuan, pemahaman, dan kemampuan peserta dalam memahami materi yang disampaikan pada kegiatan pengabdian ini. Hasil post-test menunjukkan adanya peningkatan persentase sampai pada $100 \%$ untuk pertanyaan terkait pengetahuan tentang menstruasi yang 
dikatakan normal apabila terjadi selama di rumah, perubahan fisik yang terjadi pada seseorang jika beranjak remaja, dan cara kebersihan menstruasi selama Covid-19.

Para peserta/audiens kegiatan pengabdian kepada masyarakat dapat mengikuti seluruh kegiatan pengabdian kepada masyarakat dan berperan aktif dalam kegiatan pengabdian yang ditunjukkan dengan keaktifan peserta dalam bertanya tentang bagaimana cara mengatasi menstruasi yang lama, melebihi hari normalnya, bagaimana jika menstruasi terlambat, kenapa tidak boleh menggunakan sabun pembersih pada area kewanitaan, dan bagaimana mengatasi keputihan. Selama pelaksanaan kegiatan suasana tenang dan peserta/audiens memperhatikan penyuluhan dengan penuh perhatian dan fokus, walaupun sekali-kali terjadi gangguan pada jaringan.

Waktu berlangsung kegiatan dari awal sampai akhir selama 65 menit yaitu meliputi perkenalan antar tim kegiatan pengabdian masyarakat dengan peserta/audiens yang hadir dengan menjelaskan kontrak waktu dan bahasa, penyampaian materi tentang pentingnya menjaga kesehatan pada remaja di masa pandemi covid-19 pada remaja, sesi tanya jawab mengenai topik yang belum dimengerti, serta melakukan evaluasi kembali yang termasuk dalam tahap penutup. Kegiatan ini selesai pada pukul 15.30 WIB.

Setelah dilakukan pengabdian masyarakat didapatkan hasil yang dapat dilihat dari evaluasi struktur, evaluasi proses dan dan evaluasi hasil. Evaluasi struktur didapatkan waktu mulai pelaksanaan sesuai dengan perencanaan yaitu jam 14.15 WIB, pengaturan aplikasi Zoom dan peralatan yang dibutuhkan sudah sesuai dengan yang direncanakan, pengorganisasian sesuai dengan perencanaan, audiens menyaksikan di media ruang Zoom sesuai dengan perencanaan. Evaluasi proses didapatkan pelaksanaan kegiatan mundur 15 menit dari jadwal yang sudah direncanakan, audiens berperan aktif dan dapat mengikuti kegiatan pengabdian masyarakat sebanyak 23 orang, audiens berperans serta aktif dalam kegiatan dengan aktif bertanya tentang hal yang tidak diketahui dan dipahaminya, audiens dapat mengikuti acara atau kegiatan penyuluhan sampai selesai, tim kegiatan pengabdian masyarakat hadir 20 menit sebelum kegiatan dimulai di ruang Zoom dan berperan sesuai dengan perannya. Evaluasi hasil didapatkan $80 \%$ peserta mampu memahami tentang perubahan fisik remaja selama di rumah, dan $80 \%$ peserta mampu memahami tentang manajemen kebersihan menstruasi selama pandemi Covid-19.

\section{KESIMPULAN DAN SARAN}

Ada peningkatan pengetahuan pada remaja Panti Aisyiyah Lubuk Minturun terkait pentingnya menjaga kesehatan di masa pandemi Covid-19 yang meliputi perubahan fisik 
pada remaja dan manajemen kebersihan menstruasi. Hal ini terbukti pada saat sesi diskusi dimana banyak sekali pertanyaan mengenai cara pencegahan dan penanggulangan masalah kesehatan, terutama kesehatan reproduksi. Kegiatan pengabdian ini mampu meningkatkan pengetahuan dan pemahaman remaja di masa pandemic covid-19. Metode ceramah secara daring dapat digunakan oleh tenaga kesehatan sebagai salah satu cara pendidikan kesehatan di masa pandemi covid-19 untuk meminimalkan terjadinya kontak fisik.

\section{UCAPAN TERIMA KASIH}

Ucapan terima kasih disampaikan kepada Ketua Yayasan Mercubaktijaya beserta staf dan jajaranya, Ketua Stikes Mercubaktijaya Padang beserta seluruh sivitas akademika, dan pihak terkait lainnya yang telah membantu dalam pelaksanaan kegiatan pengabdian pada masyarakat ini.

\section{DAFTAR PUSTAKA}

Cahyono A.D. dan Noeraini, A. (2016). Pengetahuan remaja putri tentang personal hygiene saat menstruasi. Jurnal AKP, 6(2): 1-5.

Kusmiran. (2012). Kesehatan Reproduksi Remaja dan Wanita. Jakarta: Salemba Medika.

Priyitno, S. (2014). Kesehatan Organ Reproduksi Wanita. Yogyakarta: Serambi Semesta Distribusi. 